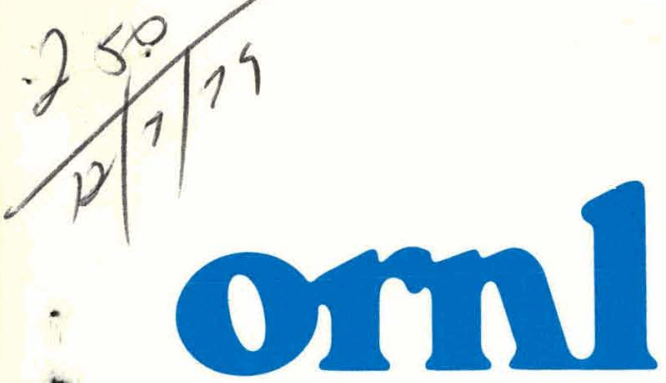

OAK

RIDGE

NATIONAL

LABORATORY

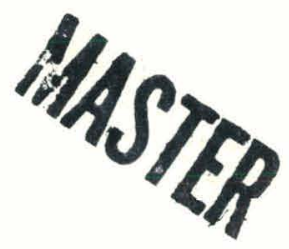

ORNL/TM-7060

\title{
Design of a Hyperbolic Microwave Metallic Lens
}

T. Uckan

OPERATED BY

UNION CARBIDE CORPORATION

FOR THE UNITED STATES

DEPARTMENT OF ENERGY 


\section{DISCLAIMER}

This report was prepared as an account of work sponsored by an agency of the United States Government. Neither the United States Government nor any agency Thereof, nor any of their employees, makes any warranty, express or implied, or assumes any legal liability or responsibility for the accuracy, completeness, or usefulness of any information, apparatus, product, or process disclosed, or represents that its use would not infringe privately owned rights. Reference herein to any specific commercial product, process, or service by trade name, trademark, manufacturer, or otherwise does not necessarily constitute or imply its endorsement, recommendation, or favoring by the United States Government or any agency thereof. The views and opinions of authors expressed herein do not necessarily state or reflect those of the United States Government or any agency thereof. 


\section{DISCLAIMER}

Portions of this document may be illegible in electronic image products. Images are produced from the best available original document. 
Printed in the United States of America. Available from National Technical Information Service

U.S. Department of Commerce

5285 Port Royal Road, Springfield, Virginia 22161

NTIS price codes-Printed Copy: A02; Microfiche A01

This report was prepared as an account of work sponsored by an agency of the United States Government. Neither the United States nor any agency thereof, nor any of their employees, makes any warranty, expressed or implied, or assumes any legal liability or responsibility for any third party's use or the results of such use of any information, apparatus, product or process disclosed in this report, or represents that its use by such third party would not infringe privately owned rights. 
Contract No. W-7405-eng-26

FUSION ENERGY DIVISION

DESIGN OF A HYPERBOLIC MICROWAVE METALLIC LENS

T. Uckan

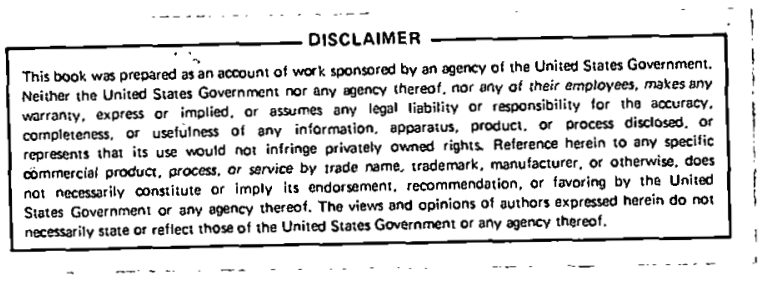

Date Publishẹd - Décémbẹr 1979

NOTICE This document contains information of a preliminary nature. It is subject to revision or correction and therefore does not represent a final report.

Prepared by the OAK RIDGE NATIONAL LABORATORY

Oak Ridge, Tennessee 37830

operated by

UNION CARBIDE CORPORATION

for the

DEPARTMENT OF ENERGY 
THIS PAGE

\section{WAS INTENTIONALLY LEFT BLANK}


CONTENTS

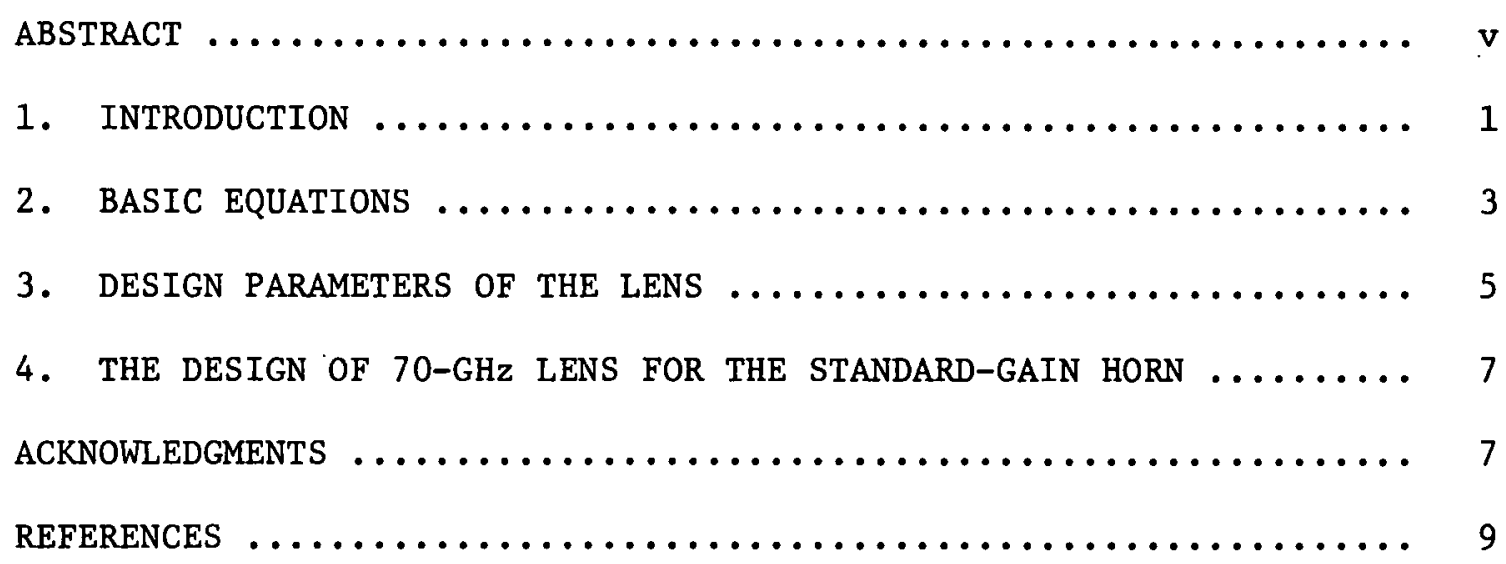


THIS PAGE

\section{WAS INTENTIONALLY \\ LEFT BLANK}




\section{ABSTRACT}

Due to problems caused by multiple reflections in the cavity walls of the EBT fusion research device, the use of a horn becomes important for the directivity of waves in the millimetric range. An ordinary dielectric lens cannot be used because of plasma-wall interactions. Microwave metallic lenses, designed to focus the energy into a plane wave, can improve the directivity considerably. By implementing a 70-GHz standard-gain horn with a delay-type hyperbolic lens, which consists of a solid metallic disk with a number of equal size small holes has indicated a gain of $15 \mathrm{~dB}$ over the no lens case. 


\section{INTRODUCTION}

The design of a multichannel microwave interferometer at $70 \mathrm{GHz}$ for the density profile measurements in EBT necessitates the use of standardgain horns. In this frequency range, directivity of the horn is not adequate and as a result multiple reflections in the cavity are a severe problem. The reflection coefficient of a metallic wall may be given by ${ }^{1}$

$$
R=1-\frac{3}{\sqrt{2}} \delta_{s}\left(\frac{\omega}{c}\right) \text {, }
$$

where

$$
\delta_{S}=\frac{c}{\sqrt{2 \pi \sigma \omega}}
$$

is the skin depth at the frequency. $\omega$, and $\sigma$ is the conductivity of the material. For aluminum walls, as in EBT, we have $\delta_{s} \simeq 3 \times 10^{-5} \mathrm{~cm}$ at $70 \mathrm{GHz}$ and $\mathrm{R}=100 \%$. Hence, the multiple reflections from the wall may distort the information at the receiving horn. Fortunately, the directivity of the horn can be improved by means of a microwave lens that produces a narrow beam, reducing multiple reflections considerably.

As we know, a microwave waveguide lens makes use of the optical properties of the rays; that is, it produces a constant-phase (a plane wave) wavefront from a spherical waveform. Figure 1 illustrates the basic construction principle of the lens that is discussed in the following sections. With proper surface selection, the ray phases can be adjusted to produce a plane wave.

An alternative approach ${ }^{2}$ to the design of the lens is to decrease the diameter of the holes rather than to change the shape of the surface, as a function of distance from the center of the lens. In practice, the tolerances of the hole sizes become important because a large number of holes of varlous sizes on the surface is required. 
-

ORNL-DWG 79-3282 FED

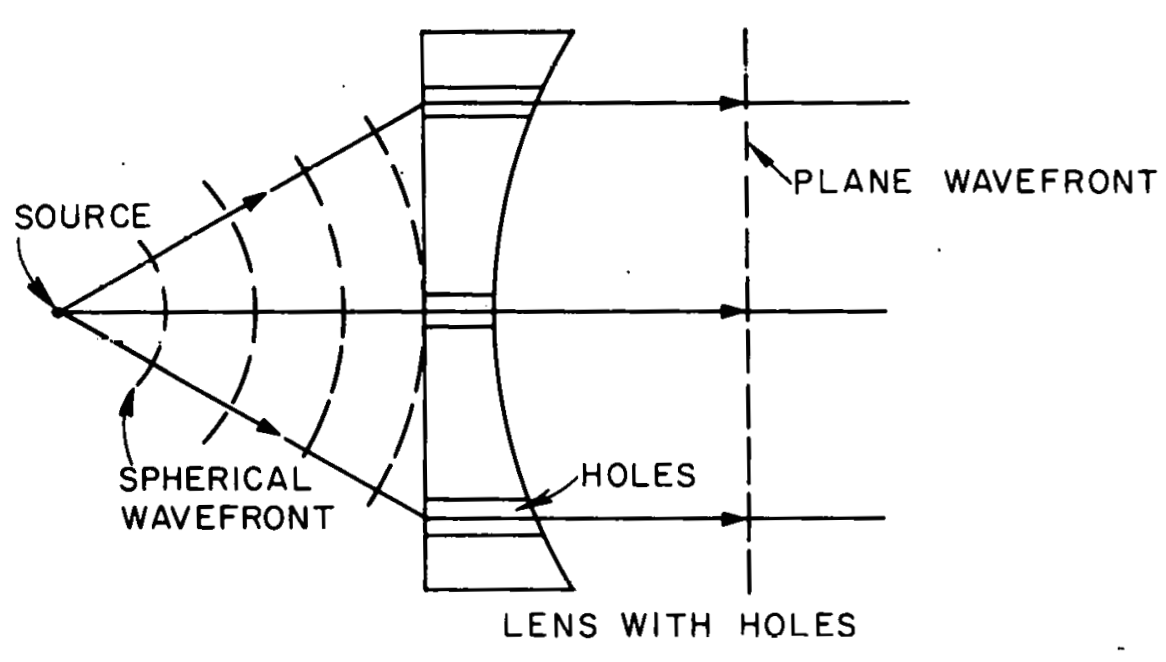

Fig. 1. Wavefronts before and after the 1 ens. 


\section{BASIC EQUATIONS}

The phase velocity, $v_{p}$, of a propagating wave in a waveguide is 3

$$
v_{p}=\frac{\omega}{2 \pi} \lambda_{g}
$$

where

$$
\lambda_{g}=\frac{\lambda}{\sqrt{1-\left(\lambda / \lambda_{c}\right)^{2}}},
$$

and $\lambda_{c}$ is the cutoff wavelength.

It should be noted from Eqs. (2) and (3) that the waveguide wavelength, $\lambda_{g}$, is greater than the free-space wavelength, $\lambda$, and thus the corresponding phase velocity is greater than the free-space velocity. A path of ray that comes out of a focal point, 0 , is shown in Fig. 2 . Considering the requirement of having a plane wavefront at $\mathrm{AA}^{\prime}$, we may write

$$
L+\varepsilon=\sqrt{y^{2}+L^{2}}+n \varepsilon
$$

where $n=\lambda / \lambda_{g}$ is the refractive index of the waveguide. Here we have made use of the fact that the time of flight of the wave must be the same for all paths from the source to the $\mathrm{AA}^{\prime}$ plane. Since $\varepsilon=\mathbf{x}-$ $(L+s)$, then the above relation reduces to an equation of hyperbola, which is

$$
\frac{(x-a)^{2}}{a^{2}}-\frac{y^{2}}{b^{2}}=1
$$

where

$$
\begin{aligned}
& \alpha=\frac{\ell}{n-1}, \\
& a=\frac{L}{1-n}, \\
& b=L,
\end{aligned}
$$




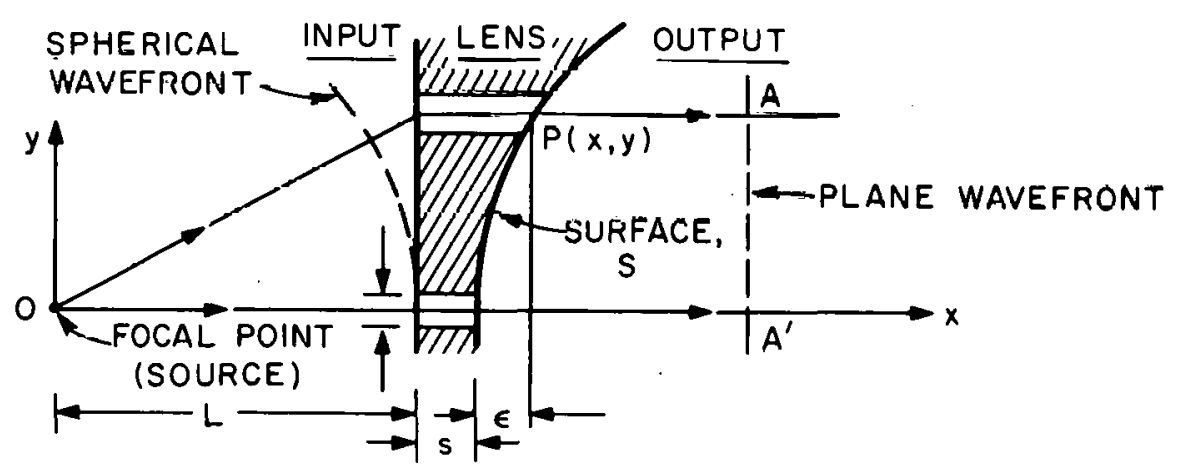

Fig. 2. Geometry of the problem. 
and

$$
\ell=n(L+s)-s .
$$

Consequently, the surface shape of the lens must be a hyperbola in order to have a plane wavefront.

\section{DESIGN PARAMETERS OF THE LENS}

The lens will be used with a microwave horn whose focal length, L, is known. The remaining parameter to be chosen is the refractive Index, $n$, of the lens. We would like to choose $n$ to minimize reflections from the lens. The power reflection coefficient from the lens is given by $^{4}$

$$
R_{L} \simeq\left(\frac{1-n}{1+n}\right)^{2} \text {. }
$$

On the other hand, $n$ depends on the cutoff frequency of the holes. For the circular holes of diameter $d$, the cutoff wavelength is given by $^{3}$

$$
\lambda_{c_{n m}}=\frac{\pi d}{v_{n m}}, \quad \text { for } T_{n m} \text { modes }
$$

and

$$
\lambda_{c_{\mathrm{nm}}}=\frac{\pi \mathrm{d}}{\nu_{\mathrm{nm}}^{\prime}}, \text { for } \mathrm{TE}_{\mathrm{nm}} \text { modes }
$$

Here, $\nu_{n m}$ and $\nu_{n m}^{\prime}$ are the mth roots of $J_{n}(x)=0$ and $J_{n}^{\prime}(x)=0$, respectively.

The $\lambda_{c}$ of the typical modes that we are interested in are given in Table 1. ${ }^{n m}$ 
Table 1. Modes of $\mathrm{TM}_{\mathrm{nl}}$ and $\mathrm{TE}_{\mathrm{nl}}$

\begin{tabular}{|c|c|c|}
\hline \multirow{2}{*}{$\begin{array}{c}\mathrm{n} \\
(\mathrm{m}=1)\end{array}$} & \multicolumn{2}{|c|}{$\lambda_{\mathrm{c}_{\mathrm{nm}}} / \mathrm{d}$} \\
\cline { 2 - 3 } & $\mathrm{TM}_{\mathrm{nl}}$ & ${ }^{\mathrm{TE}} \mathrm{nl}_{\mathrm{n}}$ \\
\hline 0 & 1.306 & 0.8198 \\
1 & 0.8198 & 1.706 \\
2 & 0.6118 & 1.028 \\
\hline
\end{tabular}

The condition for microwave propagation in a metallic guide is

$$
1-\left(\frac{\lambda}{\lambda_{c}}\right)^{2}>0
$$

or $\lambda<\lambda_{\mathrm{c}}$. Therefore, the dominant mode, $\mathrm{TE}_{11}$, propagation is

$$
\frac{d}{\lambda}>0.586
$$

But, on the other hand, the higher order modes must be avolded. In this case the second higher order mude is $\mathrm{TM}_{01}$; thuo,

$$
\frac{d}{\lambda}<0.765 \text {. }
$$

Combining Eq̣s. (9) and (10), we write

$$
0.586<\frac{d}{\lambda}<0.765 \text {, }
$$

which is the condition for the dominant TE mode propagation in the circular waveguide. Furthermore, making use of the definition of $n$, we obtain

$$
0<n<0.642 \text {. }
$$




\section{THE DESIGN OF 70-GHz LENS FOR THE STANDARD-GAIN HORN}

A 70-GHz microwave interferometer utilizes a standard-gain horn, which is shown in Fig. 3. This pyramidal microwave horn is made by flaring the waveguide in both planes. The directivity of this horn is poor, causing intolerable multiple reflections in the cavity. The lenses, which are used to focus the energy into a plane wave, are necessary.

Let us compute the design parameters of a waveguide-type hyperbolic lens that we have discussed. The dimensions of a TRG series V861 standard-gain horn are $L=9.164 \mathrm{~cm}, A=4.064 \mathrm{~cm}$, and $B=3.309 \mathrm{~cm}$. We may begin by choosing the diameter of the holes to be $d=0.125$ in. = $3.175 \mathrm{~mm}$. Then from Eq. (3) and $\lambda_{c}=1.706 \mathrm{~d}$, we find $n=0.6115<0.642$ so that the criterion, Eq. (12), is satisfied. Using the value of $n$ in Eq. (8), we find $R_{L}=6 \%$ from the lens surface.

The rest of the design parameters of the lens are easily obtained from Eq. (6) after having chosen $s=0.5 \mathrm{~cm}$ (see Fig. 4). They are $\alpha=-13.91 \mathrm{~cm}, \mathrm{a}=23.59 \mathrm{~cm}, \mathrm{~b}=9.16 \mathrm{~cm}, \mathrm{C}=1.39 \mathrm{~cm}$, and $\mathrm{D}=5.08 \mathrm{~cm}$.

The lens contains a total of 123 holes, which are placed on a brass disk in a triangular pattern. The web between the holes is about $w=0.127 \mathrm{~mm}$. With this horn-lens combination, we are able to get $a$ gain of $15 \mathrm{~dB}$ over the no lens case on the EBT cavity, which has a diameter of 22 in.

\section{ACKNOWLEDGMENTS}

The author would like to thank H. O. Eason, T. L. White, and J. B. Wilgen for stimulating discussions, and R. L. Livesey for assistance during the construction of the lens. 


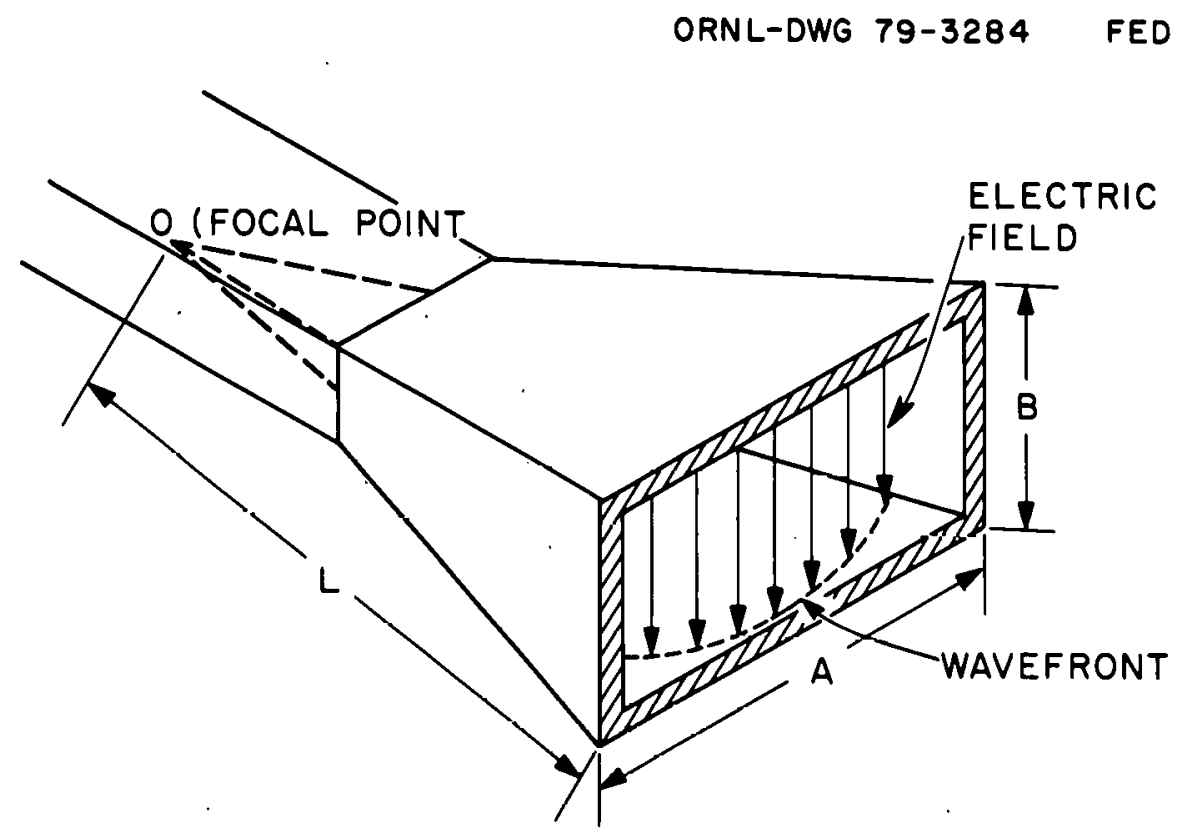

Fig. 3. Typlcal pyramidal horn.

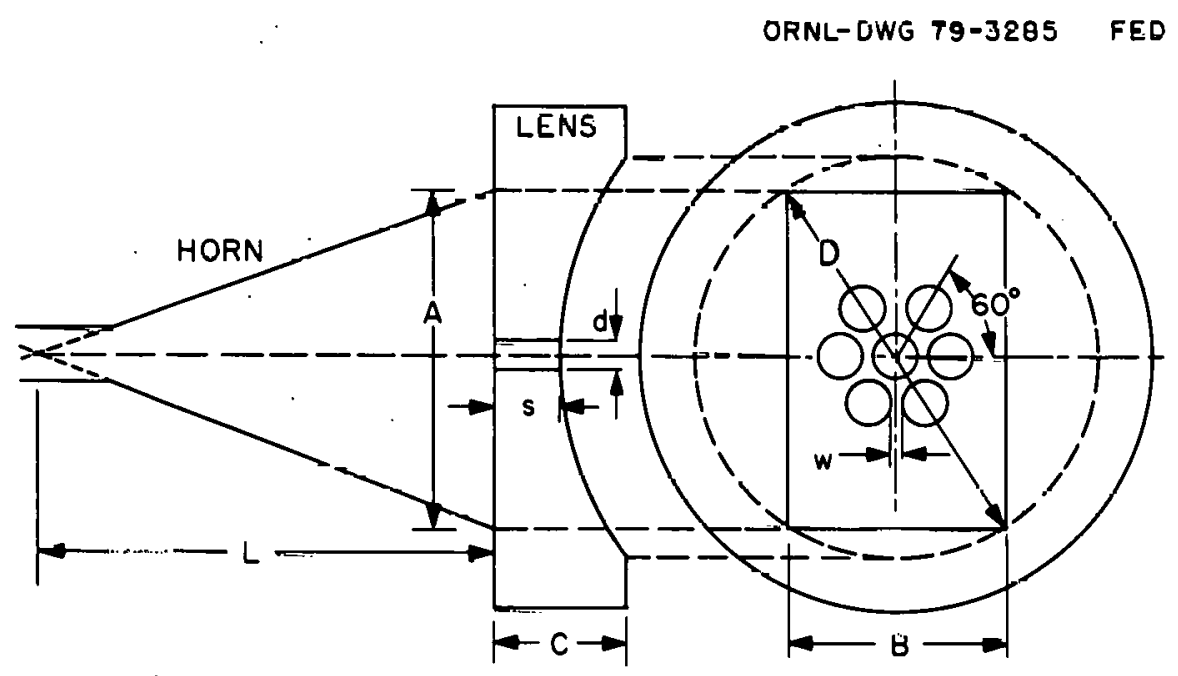

Fig. 4. The geometry of 70-GHz horn-lens combination and the hole pattern. The dimensions are: $L=9.164 \mathrm{~cm}, A=4.064 \mathrm{~cm}, B=3.309 \mathrm{~cm}$, $\mathrm{C}=1.39 \mathrm{~cm}, \mathrm{D}=5.08 \mathrm{~cm}, \mathrm{~d}=3.175 \mathrm{~mm}, \mathrm{~s}=5 \mathrm{~mm}$, and $\mathrm{w}=0.127 \mathrm{~mm}$. There are 123 holes on the lens surface. 


\section{REFERENCES}

1. Plasma Diagnostics, ed. by B. P. Konstaninov, AEC-tr-6518, Moscow (1963).

2. C. A. J. Hugenholtz, Rev. Sci. Instrum. 45, 1474 (1974).

3. R. E. Collin, Foundations for Microwave Engineering, pp. 96 and 109, McGraw-Hill, New York (1966).

4. S. Silver, Microwave Antenna Theory and Design, p. 401, McGrawHill, New York (1949). 


\section{THIS PAGE \\ WAS INTENTIONALLY \\ LEFT BLANK}


ORNL/TM-7060

Dist. Category UC-20 f, g

\section{INTERNAL DISTRIBUTION}

1. F. W. Baity, Jr.

2. R. J. Colchin

3. H. O. Eason, Jr.

4. J. C. Glowienka

5. G. R. Haste

6. D. P. Hutchinson

7. A. Komori

8. R. Livesey

9. O. B. Morgan, Jr.

10. M. W. Rosenthal

11. J. Sheffield

12. N. A. Uckan
13-32. T. Uckan

33. J. Wilgen

34-35. Laboratory Records Departmenc

36. Laboratory Records, ORNL-RC

37. Fusion Energy Division

Communications Center

38. Document Reference Section

39-40. Central Research Library

41-42. Fusion Energy Division

Library

43. ORNL Patent Office

\section{EXTERNAL DISTRIBUTION}

44. D. J. Anthony, Energy Systems and Technology Division, General Electric Company, 1 River Road, Bldg. 23, Room 290, Schenectady, NY 12345

45. C. Baker, Fusion Engineering Department, General Atomic Company, P.0. Box 81608, San Diego, CA 92138

46. J. W. Beal, Office of Confinement Systems, Office of Fusion Energy, G-234, Department of Energy, Washington, DC 20545

47. J. D. Callen, Nuclear Engineering Department, University of Wisconsin, Engineering Research Building, 1500 Johnson Drive, Madison, WI 53706

48. J. F. Clarke, Office of Fusion Energy, G-234, Department of Energy, Washington, DC 20545

49. P. L. Colestock, Princeton Plasma Physics Laboratory, P.0. Box 451, C-Site, Princeton, NJ 08540

50. R. W. Conn, Fusion Technology Program, Nuclear Engineering Department, University of Wisconsin, Madison, WI 53706

51. T. Consoli, Centre d'Etudes Nucléaires de Grenoble, B.P. 85 Centre de Tri, 38041 Grenoble Cedex, Grenoble, France

52. F. L. Culler, Electric Power Research Institute, 3412 Hillview Avenue, P.0. Box 10412, Palo Alto, CA 94304

53. R. A. Dandl, 1122 Calle de Los Serranos, San Marcos, CA 92069

54. R. C. Davidson, Applied Plasma Physics Branch, Office of Fusion Energy, G 234, Department of Energy, Washington, DC 20545

55. J. F. Decker, Applied Plasma Physics Branch, Office of Fusion Energy, G-234, Department of Energy, Washington, DC 20545

56. D. A. Dingee, Manager, Fusion Program, Battelle-Northwest, Battelle Blvd., Richland, WA 99352

57. W. R. Ellis, Jr,, Advanced Fusion Systems Branch, Office of Fusion Fnergy, G-234, Department of Energy, Washington, DC 20545 
58. H. K. Forsen, Exxon Nuclear Co., Inc., 777 106th Ave., Bellevue, WA 98009

59. T. K. Fowler, L-382, University of California, Lawrence Livermore Laboratory, P.0. Box 808, Livermore, CA 94550

60. M. Fujiwara, Institute of Plasma Physics, Nagoya University, Nagoya 464, Japan

61. H. P. Furth, Princeton University, Plasma Physics Laboratory, P.0. Box 451, Princeton, NJ 08540

62. R. W. Gould, Department of Applied Physics, California Institute of Technology, Pasadena, CA 91109

63. G. E. Guest, General Atomic Company, P.0. Box 81608, San Diego, CA 92138

64. E. G. Harris, Department of Physics, University of Tennessee, Knoxville, TN 37916

65. R. L. Hickok, Electrophysics Diviston, Rensselaer Pulytechnic Institute, Troy, NY 12181

66. S. Hiroe, Institute of Plasma Physics, Nagoya University, Nagoya 464, Japan

67. R. L. Hirsch, Sclence and Technology Department, 1251 Avenue of the Americas, New York, NY 10020

68. H. Ikegami, Institute of Plasma Physics, Nagoya University, Nagoya 464 , Japan

69. H. R. Jory, Varian Associates, 611 Hansen Way, Palo Alto, CA 94303

70. A. Kadish, Office of Fusion Energy, G-234, Department of Energy, Washington, DC 20545

71. E. E. Kintner, Office of Fusion Energy, G-234, Department of Energy, Washington, DC 205/5

72. N. A. Krall, Science Applications, Inc., 1200 Prospect Street, Box 2351, La Jolla, CA 92037

73. K. G. Moses, Chief, Reactor Engineering Branch, Office of the Assistant Director for Technical Projects, Office of Fusion Energy, G-234, Department of Energy, Washington, DC 20545

74. R. E. Price, Office of Fusion Energy, G-234, Department of Energy, Washington, DC 20545

75. B. H. Quon, TRW Defense \& Space Systems, 1 Space Park, Bldg. $\mathrm{R}-1$, Rm. 1070, Redondo Beach, CA 90278

76. D. J. Rose, Department of Nuclear Engineering, Massachusetts Institute of Technology, Cambridge, MA 02139

77. H. S. Staten, Engineering Design and Component Development Branch, D and T Program, Office of Fusion Energy, G-234, Department of Energy, Washington, DC 20545

78. D. Sweetman, Culham Laboratory, Abingdon, Uxfordshire, England OX14 3DB

79. J. M. Williams, Office of Fusion Energy, G-234, Department of Energy, Washington, DC 20545

80. H. H. Woodson, Department of Electrical Engineering, The University of Texas at Austin, Austin, TX 78712

81. Office of Assistant Manager, Energy Research and Development, Department of Energy, Oak Ridge Operations Office, Oak Ridge, TN 37830

82-329. Given distribution as shown in TID-4500, Magnetic Fusion Energy (Distribution Category UC-20 f, g, Experimental Plasma Physics and Theoretical Plasma Physics) 